\title{
OPEN Intestinal anti-inflammatory activity of Ulva ohnoi oil in DSS-induced experimental mouse model
}

\author{
JeongEun Kang ${ }^{1}$, JiSun Park ${ }^{1}$, Jung-Kil Seo ${ }^{2}$, WonHyung Choi ${ }^{3}$, SooCheol Choi ${ }^{1}$, \\ Ju-Hyoung Kim ${ }^{4} \& \ln -\mathrm{Ah} \mathrm{Lee}^{1 \bowtie}$
}

This study was conducted to examine the physiological activity of Ulva ohnoi, some of which may be used for food or natural products but could disturbing coastal ecosystems due to large scale greentide, to check values of $U$. ohnoi oil through experimental results. $U$. ohnoi oil was extracted from bulk of Ulva biomass to confirm its antioxidant and antibacterial activity, and the efficacy of $U$. ohnoi oil in the state of inflammation was confirmed through animal experiments. To confirm the antiinflammatory effect, a mouse model induced with DSS was used. As a result of measuring NO using plasma after induction of inflammation, the amount of NO produced in the $U$. ohnoi oil group was decreased compared to the control group. Expression of inflammatory cytokines TNF- $\alpha$, IL- 6 , and IL-1 $\beta$ was decreased compared to the control group. As a result of observing H\&E staining, lower crypt loss and inflammatory cell infiltration were found in the $U$. ohnoi oil group compared to the control group. Consequently, $U$. ohnoi oil appears to have great anti-inflammatory properties.

All living organisms produce reactive oxygen species (ROS), such as superoxide radical anion $\left(\mathrm{O}_{2}^{-}\right)$, hydrogen peroxide $\left(\mathrm{H}_{2} \mathrm{O}_{2}\right)$, and hydroxyl radical $(\mathrm{OH} \cdot)$, in the process of generating energy using oxygen ${ }^{1}$. ROS is also produced by external stimulation such as ozone and air pollution ${ }^{2}$. Oxidative stress caused by free radicals causes non-selective and irreversible modifications to the DNA, proteins, sugars, and lipids in living bodies, leading to aging and disease such as cancer, brain disease, heart disease, autoimmune disease, and arteriosclerosis ${ }^{3,4}$. Antioxidants are needed for protection against side effects because of the relative instability of free radicals and the possibility of damage to cells and tissues ${ }^{5}$. Therefore, many natural antioxidants, such as tocopherol and vitamin $\mathrm{C}$, and synthetic antioxidants, such as dibutyl-1-hydroxytoluene (BHT) and butylhydroxyanisole (BHA), are used in response to such problems ${ }^{6,7}$. Synthetic antioxidants are effective and economical, but high doses are known to reduce phosphatide, blood enzymes, catalase, and peroxide ${ }^{8-10}$.

Tumor necrosis factor- $\alpha$ (TNF- $\alpha$ ) is an inflammatory cytokine that was first discovered as an endotoxininduced serum factor that causes necrosis of tumors in 1975 and is known as a derivative of inflammatory responses to various infections or tumors ${ }^{11}$. Interleukin-6 (IL-6) is a multifunctional cytokine produced by B cells, $\mathrm{T}$ cells, and fibroblasts and is involved in immune and inflammatory responses ${ }^{12}$. Interleukin-1 $\beta$ (IL-1 $\beta$ ) is a potent inflammatory cytokine that is crucial for host-defense responses to infection and injury and regulates various physiological responses such as cell recruitment, appetite, sleep, and body temperature ${ }^{13}$. In macrophages, various stimuli such as cytokines, TNF- $\alpha$, and lipopolysaccharide (LPS) activate NF- $\kappa B$, a transcription factor of inflammatory responses, resulting in the expression of inducible nitric oxide synthase (iNOS) and cyclooxygenase-2 (COX-2) to produce nitric oxide (NO) and cause inflammation ${ }^{14,15}$. NO is synthesized from L-arginine by the activity of iNOS and performs various biological functions ${ }^{16}$, acting as a physiological regulator and signaling molecule. However, excessive production may contribute to tissue damage from stroke and ulcerative colitis ${ }^{17}$.

Omega-3 fatty acids are polyunsaturated fatty acids, namely, eicosapentaenoic acid (EPA) and docosahexaenoic acid (DHA), and are known to be effective against cardiovascular disease, dementia prevention, insulin resistance, and inflammation. As omega- 3 fatty acids cannot be produced from the body and must be obtained from dietary sources ${ }^{18}$, extracting EPA and DHA from fish involves problems related to marine pollution ${ }^{19}$.

${ }^{1}$ Department of Chemistry, Kunsan National University, Gunsan 54150, Korea. ${ }^{2}$ Department of Food Science and Bitoechnology, Kunsan National University, Gunsan 54150, Korea. ${ }^{3}$ Department of Infection Biology, School of Medicine, Wonkwang University, Iksan 54538, Korea. ${ }^{4}$ Department of Aquaculture and Aquatic Science, Kunsan National University, Gunsan 54150, Korea. ${ }^{\circledR}$ email: leeinah@kunsan.ac.kr 
The Antarctic krill (Euphausia superba) is a zooplankton found in the Antarctic water that feeds directly on minute phytoplankton. This species is receiving the spotlight as a food resource in the future due to its excellent nutritional value ${ }^{20}$, as it contains large amounts of unsaturated fatty acids and antioxidants such as EPA and $\mathrm{DHA}^{21}$. However, krill contains a large amount of fluoride, which is harmful to the human body ${ }^{22}$. There are also reports that global warming is accelerating due to the decline in krill populations. Therefore, it is urgent to find a replacement because overfishing of krill threatens the survival of other marine life such as whales, penguins and seals ${ }^{23}$.

Seaweeds are known to accumulate many elements on from the surrounded environments. In particular, seaweeds absorb these elements over their entire surface area and are a treasure trove of minerals up to tens of thousands of times compared to pelagic organisms ${ }^{24}$. Although seaweeds have low nutritional value due to their low protein and fat content, they have antioxidant effects such as scavenging free radicals within the tissue ${ }^{25,26}$ due to their high content of various inorganic salts, such as potassium, iodine, and calcium, and vitamins A and $\mathrm{C}^{27}$. Recently, as the interest in finding substances with pharmacological action from natural plants has increased, efforts to extract effective active ingredients and use them as food additives or pharmaceuticals are growing alongside research on the physiological activity of sea weeds ${ }^{28,29}$.

Ulva ohnoi is a green alga in the family Ulvaceae (Chlorphyta) widely distributed around the North America, South Korea, Japan, and Mediterranean sea, usually attached to hard bottom on the rocky shore. The rise of sea surface temperature and nutritive salts due to global warming causes mass reproduction of $U$. ohnoi ${ }^{30}$, causing large scare green-tide in some contaminated costal ecosystem, such as Japan ${ }^{31}$, and South Korea ${ }^{30}$. U. ohnoi has a fast growth rate, so no problem of material depletion is raised, and it is thought that it is valuable as a new marine natural product while solving environmental problems. About 700 tons of $U$. ohnoi were collected in blooming area in Japan, and some algal biomass were used as food ingredients ${ }^{31}$. In addition, morphologically similar green alga, U. lactuca has been used for food in Europe for a long time, and multiple studies have been performed on its various food and physiological activities. It contains a large amount of polysaccharides containing sulfuric acid, and this acid polysaccharide has been reported to have anti-viral, immunity-boosting, and anti-cancer effects ${ }^{32}$. Some studies in South Korea reported anti-cancer effects and immune activities by extracting glycoproteins from single-cell layered green algal, Monostroma nitidum ${ }^{32}$.

The purpose of this study is to extract oil from U. ohnoi using an organic solvent extraction method to find out the utility of $U$. ohnoi oil for its physiological activity. There have been various efficacy studies using U. ohnoi, but studies using U. ohnoi oil are insufficient. Conventionally, oily ingredients such as krill oil and omega-3 are exerting the function of maintaining human health. We would like to consider the aspect of recycling discarded $U$. ohno $i$ through the use as a new material by proving the functionality of $U$. ohnoi, the subject of our research.

\section{Materials and methods}

Instruments and reagents. In this experiment, DPPH (1,1-diphenyl-2-picrylhydrazyl) (Sigma-Aldrich, USA), folin\&ciocalteu's reagent (sigma-Aldrich, USA), bacto agar (BD DIFCO, USA), bacto tryptic soy broth (BD DIFCO, USA), NO (nitric oxide) kit (Cell Biolabs. INC., USA), ELISA (enzyme-linked immunosorbent assay) kit (Abfrontier, KOR), TRIzol reagent (Sigma-Aldrich, USA), chloroform (Daejung, KOR), isopropyl alcohol (Sigma-Aldrich, USA), ethanol (Daejung, KOR), DEPC (diethyl pyrocarbonate) water (Thermo Scientific, USA), agarose (Bioneer, KOR), RT-PCR premix kit (Bioneer, KOR), Hematoxylin (Sigma-Aldrich, USA), Eosin Y (Sigma-Aldrich, USA ), centrifuge (Labogene, KOR), enzyme-linked immunosorbent assay (ELISA) reader (Thermo Scientific, USA), fluoro box (Neo Science, KOR), and Permount (Fisher, USA) were used.

Experimental material. The U. ohnoi used in this study was collected from the north-east part of Jeju

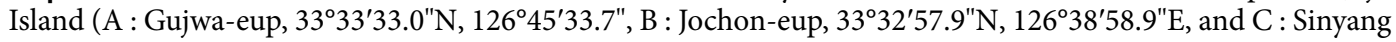
sand beach, $33^{\circ} 26^{\prime} 06.0^{\prime \prime} \mathrm{N}, 126^{\circ} 55^{\prime} 23.4^{\prime \prime} \mathrm{E}$ ) in 2019 (voucher specimen number ELMV 03; deposited in the herbarium of ELMV laboratory in Kunsan National University; collector: JuHyoung Kim). We have transported small amount of Ulva biomass collected from the blooming area to the laboratory, thus sample collection was not threatened with endangered species and have not destroyed natural seaweed habitats. In addition, sampling was carried out after permission of National Research Foundation (NRF) of South Korea, thus government is permitting the collection of Ulva because it is working on a research project to manage Ulva biomass. Sample were washed with tap water and distilled water several times, and dried in an oven at $60^{\circ} \mathrm{C}$. Organic solvent extraction was performed to extract $U$. ohnoi oil. The weight of the dried sample in the beaker was $29.3 \mathrm{~g}, 33.5 \mathrm{~g}$, and $30.7 \mathrm{~g}$ of A, B, and C, respectively, and $200 \mathrm{ml}$ of hexane was added per $10 \mathrm{~g}$. Thereafter, extraction was performed at room temperature for $48 \mathrm{~h}$ and the organic solvent was removed using speed vacuum. The yields are $0.19 \%$, $0.23 \%$, and $0.21 \%$ for $\mathrm{A}, \mathrm{B}$, and C, respectively. All the experiments involving plants adhered to relevant ethical guidelines on plant usage. Krill oil is manufactured by Neptune (Neptune Technologies \& Bioressources INC., Canada), and omega-3 is manufactured by Now Foods (Now Foods, USA). The composition of krill oil, omega3 , and U. ohnoi oil used in the experiment is shown in Table S1 of Supplementary Information.

DPPH radical scavenging activity measurement. DPPH radical scavenging activity was used to eliminate absorption characteristics when the compound was stabilized by receiving electronic or hydrogen radicals and measured in accordance with using 1,1-diphenyl-2-picryhydrazyl (DPPH) ${ }^{33}$. DPPH was dissolved in ethanol at a final concentration of about $0.2 \mathrm{mM}$. U. ohnoi oil ( $100 \mu \mathrm{l})$ by concentration was added to $0.1 \mathrm{ml}$ of ethanol solution of DPPH. After blocking the light and reacting for $20 \mathrm{~min}$, the absorbance was measured at $517 \mathrm{~nm}$. DPPH scavenging effect was calculated from $\left[1-\left(A b s_{\text {sample }}-A b s_{\text {blank }}\right) / A b s_{\text {control }}\right] \times 100$, where $A b s_{\text {sample }}$ is the absorbance of the sample, and $\mathrm{Abs}_{\text {blank }}$ is the absorbance of the color control, and $\mathrm{Abs}_{\text {control }}$ is the absorbance 
of the negative control. As a control group, ethanol was added instead of the sample. L-ascorbic acid, which is known to have high antioxidant capacity, was used as a control to compare antioxidant activity.

Total polyphenol content assay. The total polyphenol content assay (TPA) was determined using the Folin-Denis reagent ${ }^{34} .200 \mu \mathrm{l}$ of the $U$. ohnoi oil was added to $1 \mathrm{ml}$ of $0.2 \mathrm{~N}$ folin-ciocalteu reagent and $800 \mu \mathrm{l}$ of $7.5 \% \mathrm{Na}_{2} \mathrm{CO}_{3}$ was added. After blocking the light and reacting at room temperature for $2 \mathrm{~h}$, the absorbance was measured at $620 \mathrm{~nm}$ using a spectrophotometer. Gallic acid was used as a standard reagent, and polyphenol content was calculated using a standard curve. The TPA was expressed as gallic acid equivalents (GAE) in mg/1 g material.

URDA (ultrasensitive radical diffusion assay). The antibacterial activity measurement using U. ohnoi oil was performed by URDA (ultrasensitive radical diffusion assay) method ${ }^{35}$. The sample was prepared at a concentration of $10 \mathrm{mg} / \mathrm{ml}$ using $0.01 \%$ acetic acid (HAc). The strains used were gram-positive bacteria Bacillus subtilis KCTC1021, gram-negative bacteria Escherichia coli D31, and fungus Candidia albicans KCTC76965. Each strain was inoculated with 1 platinum loop in tryptic soy broth (TSB) medium and pre-culture was performed at $37^{\circ} \mathrm{C}$ for $24 \mathrm{~h}$. The activated bacteria measured absorbance at $630 \mathrm{~nm}$ to make the O.D value of the bacteria 0.01 ( $0.5 \mathrm{McF}$ ). $0.03 \%$ TSB, sabouraud’s dextrose broth (SDB), $1 \%$ agarose, and $10 \mathrm{mM}$ phosphate buffer (pH 6.5) were added to the underlay gel at $9.5 \mathrm{ml}$ concentrations and then poured into the plate to solidify. The plate was pierced with a diameter of $2.5 \mathrm{~mm}$ and $5 \mu \mathrm{l}$ of sample was injected into each well. All samples were tested with $0.01 \%$ acetic acid $5 \mu \mathrm{l}$, which was not affected by solvent. After the first culture at $37^{\circ} \mathrm{C}$ for $3 \mathrm{~h}, 10 \mathrm{ml}$ overlay gel containing $6 \%$ TSB, SDB, $1 \%$ agarose, and $20 \mathrm{mM}$ phosphate buffer (pH 6.5) was poured into the cell, and then solidified at room temperature, and then the clear zone was confirmed after the second culture at $37^{\circ} \mathrm{C}$ for $24 \mathrm{~h}$.

Characterization of antibacterial activators using enzymatic treatment. In order to confirm the properties of the antibacterial activity in the U. ohnoi oil, various enzymes were treated to determine whether there was any change in antibacterial activity. The enzymes used in the experiment are trypsin, chymotrypsin, lipase, $\alpha$-amylase, pronase, and proteinase. $5 \mu \mathrm{l}$ of $U$. ohnoi oil at a concentration $10 \mathrm{mg} / \mathrm{ml}$ was mixed with 1 $\mu \mathrm{l}$ of each enzyme and incubated for $3 \mathrm{~h}$ at $37^{\circ} \mathrm{C}$, followed by secondary culture at $37{ }^{\circ} \mathrm{C}$ for $24 \mathrm{~h}$. The cultured extracts were tested for URDA against B. subtilis, E. coli, and C. albicans.

Experimental animals and inflammatory intestine disease induction. Male ICR mouse aged 4 weeks were obtained from Orient bio (Orient bio, Gwangju). They were housed in a controlled environment $\left(25 \pm 2{ }^{\circ} \mathrm{C}, 50 \pm 10 \%\right.$ humidity) with a $12 \mathrm{~h}$ light/dark cycle. The animals allowed to free access to food and filtered water. They were quarantined and acclimatized for 1 week before use. The animals were kept in groups of 6 per cage. After 1 week habituation period, the experimental animals were classified into five groups as follows: one is normal, another is control and the others is DSS + krill oil (KO), DSS + omega-3 ( $\omega-3)$, and DSS + U. ohnoi oil (UO). Krill oil, $\omega-3$, and $U$. ohnoi oil are prepared using distilled water at concentrations of $100 \mathrm{mg} / \mathrm{kg}, 100 \mathrm{mg} /$ $\mathrm{kg}$, and $25 \mathrm{mg} / \mathrm{kg}$ and administered orally at $100 \mu \mathrm{l}$ each for 10 days (Table S2). U. ohnoi oil used for mouse administration was prepared by mixing a certain amount of A, B, and C. To induce inflammatory bowel disease, the Con, KO, $\omega-3$, and UO groups freely ingested 5\% dextran sulfate sodium (DSS) dissolved in distilled water for 7 days after 4 days of sample administration. The body weight of the experimental animals was measured at the same time every day and is shown in Figure S1 of Supplementary Information. The animal studies were approved by Kunsan National University animal experiment ethics committee (Approval No: 2020-02). This study was carried out in compliance with the Animal Research: Reporting of In Vivo Experiments (ARRIVE) guidelines. All the experiments involving animals adhered to relevant ethical guidelines on animal usage.

Measurement of NO production. The amount of NO production was measured using plasma of 6 mice per group, and Griess reagent was used ${ }^{36}$. Blood was collected to obtain plasma and centrifuged at $7000 \mathrm{rpm}$ for 10 min at $4{ }^{\circ} \mathrm{C}$. NO concentration was then determined by the addition of $50 \mu \mathrm{l}$ each Griess reagents 1 and 2. After incubation for $10 \mathrm{~min}$ at room temperature, the absorbance was read at $540 \mathrm{~nm}$.

Measurement of inflammatory cytokine in colon tissue. In this study, colon tissue from 6 mice per group was removed and used, $1 \mathrm{ml}$ of $1 \times$ phosphate-buffered saline (PBS) was added, crushed, and centrifuged at $7000 \mathrm{rpm}$ for $10 \mathrm{~min}$, and then the supernatant was taken. The amount of inflammatory cytokine TNF- $\alpha$, IL-6, and IL- $1 \beta$ was measured using an enzyme-linked immunosorbent assay (ELISA) kit. After adding $100 \mu \mathrm{l}$ of antigen to the antibody-coated plate, incubated at $37^{\circ} \mathrm{C}$ for $2 \mathrm{~h}$, and washed 3 times using a washing buffer. After the addition of $100 \mu \mathrm{l}$ of the secondary antibody, it was incubated at $37^{\circ} \mathrm{C}$ for $1 \mathrm{~h}$ and washed 3 times. After adding $100 \mu \mathrm{l}$ of the $\mathrm{TMB}$ solution, incubate at $37^{\circ} \mathrm{C}$ for $30 \mathrm{~min}$, and reacted at room temperature for $10 \mathrm{~min}$ after adding $100 \mu$ of stop solution, absorbance was measured at $450 \mathrm{~nm}$.

RT-PCR. RNA used in the experiment was extracted from the colon tissue of the mouse using TRIzol reagent, and it was dissolved in $50 \mu$ diethyl pyrocarbonate (DEPC) water. Reverse transcription-polymerase chain reaction (RT-PCR) is performed using and RT-PCR premix kit, and $300 \mathrm{ng}$ of total RNA, 20 pmol of each of forward and reverse primers are added to use a total of $20 \mu \mathrm{l}$ of the reaction solution. The cDNA was synthesized by reacting at $50^{\circ} \mathrm{C}$ for $30 \mathrm{~min}$ and $94^{\circ} \mathrm{C}$ for $5 \mathrm{~min}$, followed by 35 cycles of denaturation at $94^{\circ} \mathrm{C}$ for $40 \mathrm{~s}$, annealing at $58^{\circ} \mathrm{C}$ for $40 \mathrm{~s}$, and extension at $72^{\circ} \mathrm{C}$ for $90 \mathrm{~s}$. The PCR product was confirmed by electrophoresis on $1.2 \%$ agarose gel, and GAPDH was used as control. The primer sequence used in the experiment is as follows Table 1. 


\begin{tabular}{|l|l|l|}
\hline \multirow{2}{*}{ Gene } & Forward/reverse & Sequences (5' to 3') $^{\text {') }}$ \\
\hline \multirow{2}{*}{ TNF- $\alpha$} & $\mathrm{F}$ & GGCAGGTCTATTTGGAGTCATTGC \\
\cline { 2 - 3 } & $\mathrm{R}$ & ACATTCGAGGTCCAGTGAATTCGG \\
\hline \multirow{2}{*}{ IL-6 } & $\mathrm{F}$ & TGGAGTCACAGAAGGAGTGGCTAAG \\
\cline { 2 - 3 } & $\mathrm{R}$ & TCTGACCACAGTGAGGAATGTCCAC \\
\hline \multirow{2}{*}{ IL-1 $\beta$} & $\mathrm{F}$ & GCCTTGGGCCTCAAAGGAAAGAATC \\
\cline { 2 - 3 } & $\mathrm{R}$ & GGAAGACACAGATTCCATGGTGAAG \\
\hline \multirow{2}{*}{ COX-2 } & $\mathrm{F}$ & GCAAATCCTTGCTGTTCCAATC \\
\cline { 2 - 3 } & $\mathrm{R}$ & GGAGAAGGCTTCCCAGTTTTG \\
\hline \multirow{2}{*}{ GAPDH } & $\mathrm{F}$ & CATGGCCTTCGTGTTC \\
\cline { 2 - 3 } & $\mathrm{R}$ & CCTGGTCCTCAGTGTAGC \\
\hline
\end{tabular}

Table 1. Sequences of primers used for RT-PCR.

H\&E staining using colon tissue. Hematoxylin \& eosin ( $\mathrm{H} \& \mathrm{E})$ staining is primarily used in histology to visualize the structure of tissues ${ }^{37}$. H\&E stains are still essential for recognizing various tissue types and the morphologic changes that form the basis of contemporary cancer diagnosis ${ }^{38}$. Each specimen was sectioned into a thickness of $7 \mu \mathrm{m}$ and histochemical staining was performed using hematoxylin and eosin. For deparaffinization, xylene was added and repeated three times for $5 \mathrm{~min}$, and xylene was removed in the order of $100 \%, 95 \%$, and $70 \%$ ethanol. For nuclear staining, it was stained with hematoxylin solution for 5 min, and then washed with flowing water. Hematoxylin was removed using $1 \% \mathrm{HCl}$ solution and $1 \%$ ammonia solution, followed by immersion in eosin solution for $2 \mathrm{~min}$ to stain the cytoplasm. Then, it was dehydrated in the order of $70 \%, 95 \%$, and $100 \%$ ethanol. To remove alcohol, it was put in xylene and repeated three times for $3 \mathrm{~min}$, and then the cover glass was and sealed.

\section{Results and discussion}

Antioxidant activity evaluation. The antioxidant activity of $U$. ohnoi oil was measured using DPPH and Folin-Denis reagent. The radical scavenging ability was measured by concentrations of $0.1,0.3,0.5,0.7$, and $1 \mathrm{mg} / \mathrm{ml}$, and ascorbic acid was used as a positive control (Fig. 1A). It was confirmed that the DPPH radical scavenging activity of $\mathrm{A}$ and $\mathrm{B} U$. ohnoi oil increased to $0.7 \mathrm{mg} / \mathrm{ml}$, but decreased at the concentration of $1 \mathrm{mg} / \mathrm{ml}$. At the concentration of $0.7 \mathrm{mg} / \mathrm{ml}, \mathrm{B} U$. ohnoi oil showed the most similar value to ascorbic acid at $86.71 \pm 8.36 \%$. Ascorbic acid showed $88 \%$ scavenging activity independent of concentration.

The total phenolic compound content of the sample was curve using gallic acid as the standard and converted to gallic acid equivalents (GAE) (Fig. 1B). The total polyphenol content was $107.45 \pm 0 \mathrm{mg}$ GAE/g in B and $69.44 \pm 3.46 \mathrm{mg} \mathrm{GAE} / \mathrm{g}$ in $\mathrm{C}$, which was about 1.5 times higher than that of B U. ohnoi oil. Krill oil showed a lower polyphenol content than B U. ohnoi oil at $70.6 \pm 1.99 \mathrm{mg} \mathrm{GAE} / \mathrm{g}$.

Antibacterial activity of $U$. ohnoi oil by strain. The antibacterial activity of $U$. ohnoi oil was measured against B. subtilis, E. coli, and C. albicans strains using the URDA method. In general, B. subtilis and E. coli showed antibacterial activity, but not against the fungus $C$. albicans. The size of the clear zone was $10.36 \mathrm{~mm}$ in $\mathrm{B}$ and $7.35 \mathrm{~mm}$ in $\mathrm{A}$ in the B. subtilis strain, indicating that the clear zone size was 1.41 time higher than that of B U. ohnoi oil. As a result of measuring the activity against E. coli strains, all three types of U. ohnoi oil showed high antibacterial activity of $10 \mathrm{~mm}$ or more (Table $2 \mathrm{~A}$ ).

Changes in antibacterial activity by enzyme treatment. To confirm the characteristics of substances exhibiting antibacterial activity in U. ohnoi oil, six enzymes such as protease and lipolytic enzyme were treated, respectively, and then it was confirmed whether there was any change in antibacterial activity. As enzymes, trypsin, chymotrypsin, lipase, $\alpha$-amylase, pronase, and proteinase $\mathrm{K}$ were used, and the size of the clear zone was measured to show antibacterial activity according to the enzyme treatment (Table 2B). B. subtilis, E. coli, and C. albicans strains were tested for activity changes, but the antibacterial activity of $U$. ohnoi oil was not significantly affected by the enzymes used. Therefore, it was confirmed that the substance exhibiting antibacterial activity in U. ohnoi oil is considered to an organic compound rather than a fat or proteinaceous substance that is cleaved by enzyme treatment and has stability in enzyme reaction.

NO production measurement. NO (nitric oxide) is known as a mediator of the inflammatory response secreted when cells stimulated by inflammatory substances such as LPS or TNF- $\alpha$ induce inflammation ${ }^{39}$. In this study, the amount of NO production was measured using plasma of mice (Fig. 2A). The NO production of the control group was $31.26 \pm 5.04 \mu \mathrm{M}$, which was about 1.3 times higher than that of the normal group, and it was found that there is an effect of inducing inflammation by DSS. The production amount of the UO group was $26.26 \pm 4.08 \mu \mathrm{M}$, which was about $84.0 \%$ lower than that of the control group, and it was confirmed that the production amount of $\mathrm{NO}$ was like that of the normal group. 

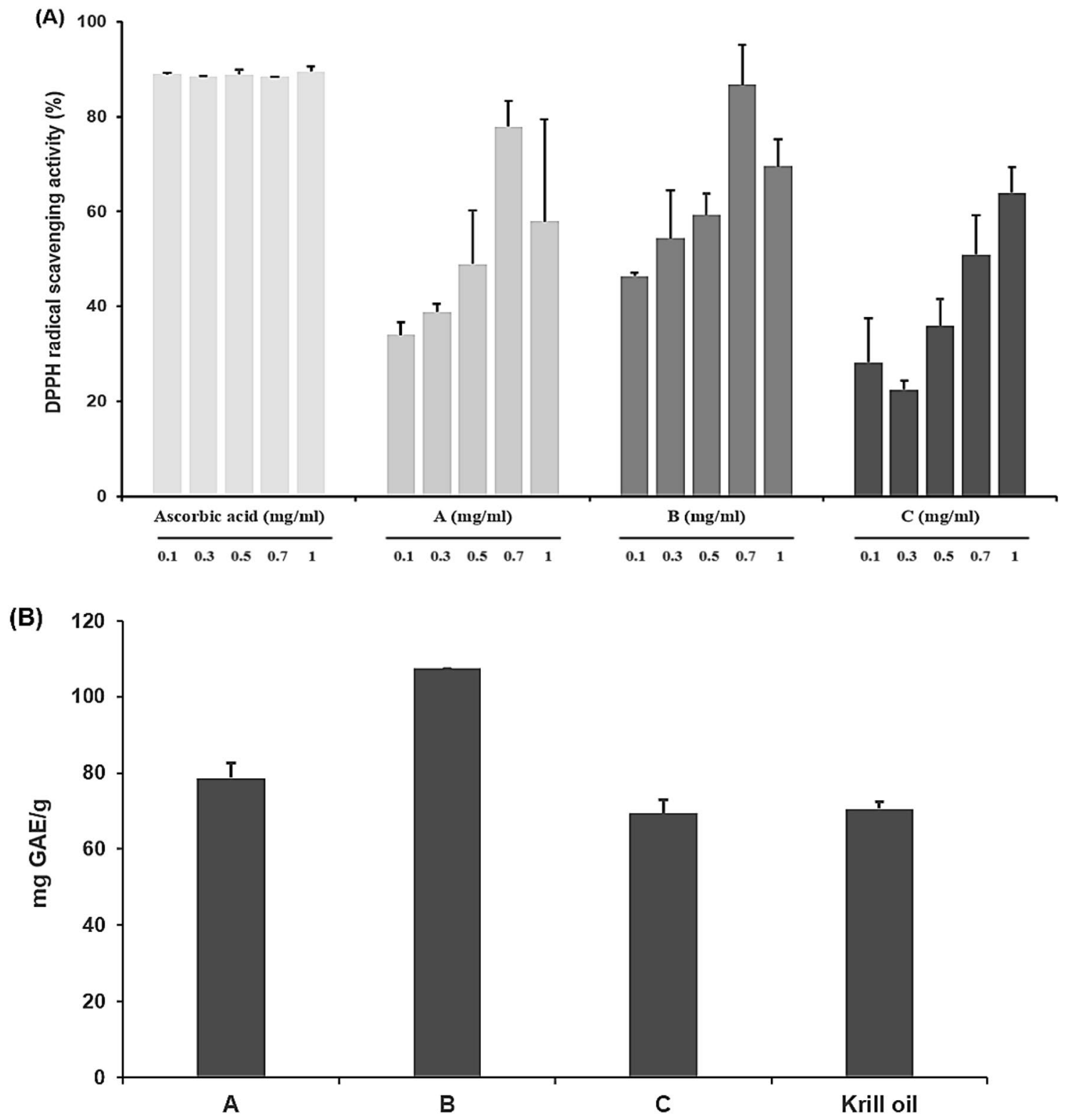

Figure 1. (A) DPPH radical scavenging activity of regional U. ohnoi oil at various concentrations. (B) Total polyphenol content of $U$. ohnoi oil by region.

Inflammatory cytokine production. The amount of TNF- $\alpha$, IL-6, and IL-1 $\beta$ production were measured by ELISA method. All three cytokines were increased in the control group. In the case of TNF- $\alpha$ and IL- 6 , the amount of production of $43.9 \pm 20.2 \mathrm{pg} / \mathrm{ml}$ and $17.41 \pm 2.68 \mathrm{pg} / \mathrm{ml}$, respectively, in the UO group and significantly decreased compared to the control group (Fig. 2B,C). The amount of IL- $1 \beta$ produced in the UO group was $54.68 \pm 14.14 \mathrm{pg} / \mathrm{ml}$, which was like that of the normal group, but there was no statistical significance (Fig. 2D).

Confirmation of inflammatory cytokine mRNA expression. RT-PCR was performed using the colon tissue of experimental animals induced with 5\% DSS to determine whether inflammatory cytokine affects mRNA expression. The results are as follows (Fig. 3). When compared with the normal group, it was confirmed that the amount of inflammatory factor expression in the control group was increased. It was confirmed that the expression amount of the U. ohnoi oil administration group decreased compared to the control group, but there was no significant difference in the case of TNF- $\alpha$.

Histochemical observation. The histological examination of the intestine was evaluated for morphological changes through hematoxylin and eosin (H\&E) staining, and observed using an optical microscope. The normal group represents typical colon tissue, but the control group lost crypt and destroyed the nucleus (Fig. 4). On the other hand, in the U. ohnoi oil-administered group, submucosal infiltration was observed compared to the normal group, but the degree of crypt and tissue damage was lower than that of the control group. 


\begin{tabular}{|c|c|c|c|c|c|c|c|c|}
\hline \multicolumn{3}{|l|}{ (A) } & & & & & & \\
\hline Bacterial strain & Region & Clear zone $(\mathrm{mm})$ & & & & & & \\
\hline \multirow{3}{*}{ B. subtilis } & A & 7.35 & & & & & & \\
\hline & B & 10.36 & & & & & & \\
\hline & C & 9.73 & & & & & & \\
\hline \multirow{3}{*}{ E. coli } & A & 12.38 & & & & & & \\
\hline & B & 12.25 & & & & & & \\
\hline & C & 10.36 & & & & & & \\
\hline \multirow{3}{*}{ C. albicans } & A & - & & & & & & \\
\hline & B & - & & & & & & \\
\hline & C & - & & & & & & \\
\hline \multicolumn{9}{|l|}{ (B) } \\
\hline & & NT & $\mathrm{T}$ & C & $\mathbf{L}$ & $\mathbf{A}$ & $\mathbf{P}$ & $\mathbf{K}$ \\
\hline \multirow{3}{*}{ B. subtilis } & A & 10.69 & 11.44 & 9.42 & 10.82 & 9.70 & 10.19 & 9.56 \\
\hline & B & 10.57 & 9.06 & 8.73 & 8.83 & 8.33 & 8.77 & 8.64 \\
\hline & C & 9.17 & 8.36 & 9.19 & 9.12 & 8.70 & 9.15 & 9.90 \\
\hline \multirow{3}{*}{ E. coli } & A & 14.67 & 14.33 & 14.00 & 13.83 & 13.38 & 13.57 & 14.21 \\
\hline & B & 11.02 & 10.27 & 9.46 & 9.89 & 10.00 & 10.45 & 10.32 \\
\hline & C & 12.22 & 10.98 & 11.61 & 9.41 & 8.98 & 9.63 & 9.98 \\
\hline \multirow{3}{*}{ C. albicans } & A & - & - & - & - & - & - & - \\
\hline & B & - & - & - & - & - & - & - \\
\hline & C & - & - & - & - & - & - & - \\
\hline
\end{tabular}

Table 2. (A) Size of clear zone by U. ohnoi oil. (B) Size of clear zone by U. ohnoi oil after with treatment enzyme (NT HAc $0.01 \%$ acetic acid, $T$ trypsin, $C$ chymotrypsin, $L$ lipase, $\alpha \alpha$-amylase, $P$ pronase, $K$ proteinase $\mathrm{K})$ (unit of measurements: $\mathrm{mm}$ ).

(A)
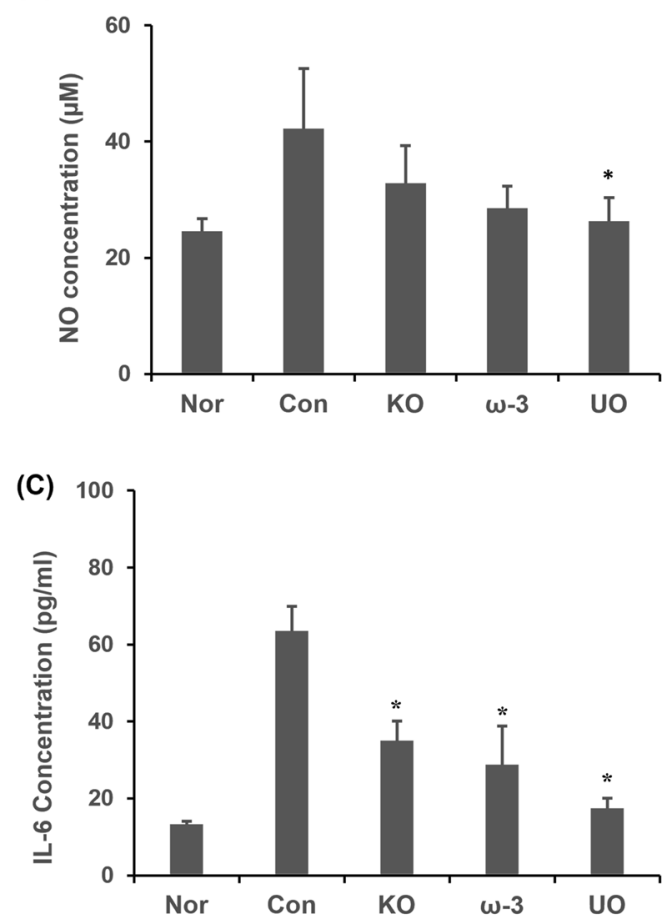

(B) 800

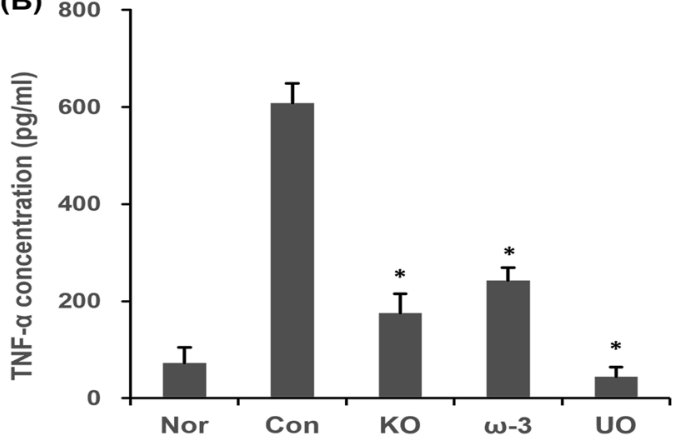

(D)

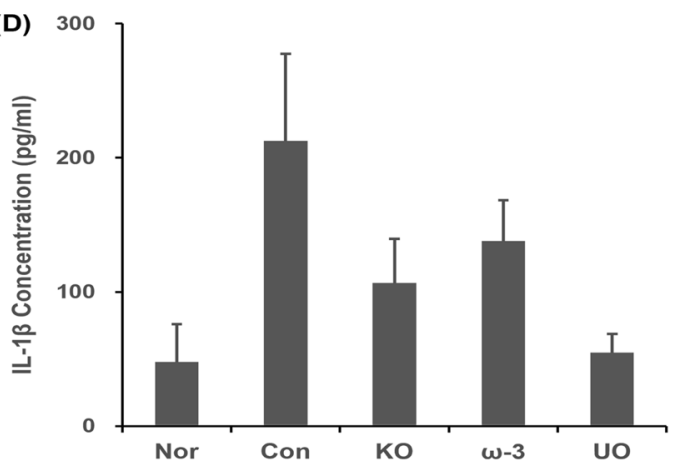

Figure 2. (A) Effect of $U$. ohnoi oil on nitric oxide production in mouse plasma. Data obtained for group were analyzed ANOVA compared control group. Significantly different from control group $\left({ }^{*} \mathrm{p}<0.05\right)$. Effect of $U$. ohnoi oil according to the (B) TNF- $\alpha$, (C) IL-6, and (D) IL-1 $\beta$ production in the colon tissue of mice induced by DSS. Data obtained for group were analyzed ANOVA compared control group. Significantly different from control group ${ }^{*} \mathrm{p}<0.05, \mathrm{n}=6$. 
(B)

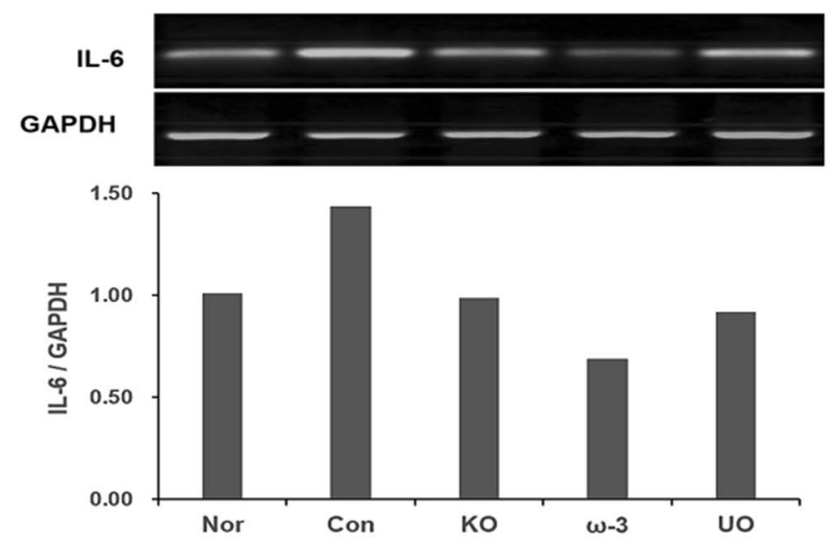

(C)
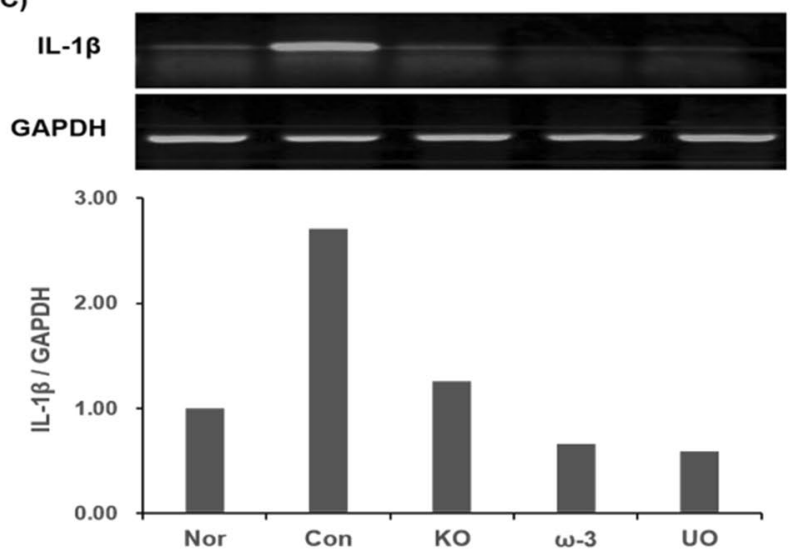

(A)
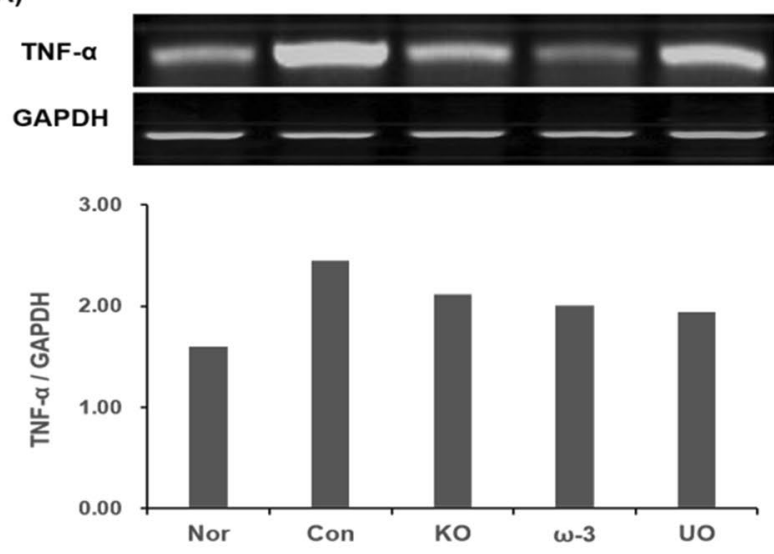

(D)
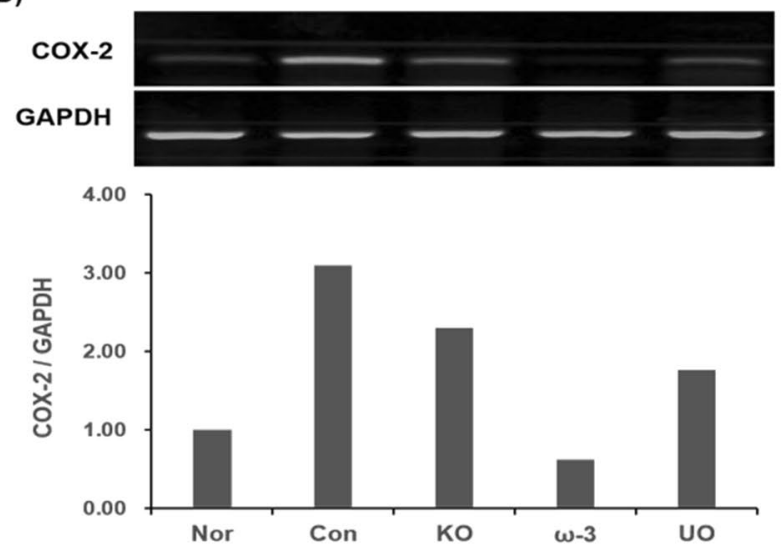

Figure 3. Inhibitory effects of $U$. ohnoi oil extracts on the mRNA expression of inflammatory cytokine.

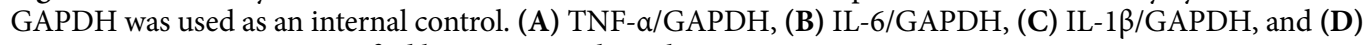
COX-2/GAPDH were quantified by a numerical graph. $n=6$.

\section{Discussion}

This study recognized the superiority of $U$. ohnoi, a species of green algae known for its immune activity, based on the results of prior research using $U$. ohnoi extracts to investigate its effects on physiological activity. This study conducted experiments to evaluate the antioxidant, antibacterial activities of the U. ohnoi oil, and measured its anti-inflammatory activity by using a DSS-induced inflammatory bowel disease mouse model. As a result of measuring DPPH radical scavenging activity to evaluate the antioxidant activity of $U$. ohnoi oil, the radical scavenging activity of A and B U. ohnoi oil was $77.85 \pm 5.39 \%$ and $86.71 \pm 8.36 \%$, respectively, at $0.7 \mathrm{mg} / \mathrm{ml}$, showing the highest activity. In particular, B U. ohnoi oil showed similar activity to the control substance, ascorbic acid. When the total polyphenol was measured, it was confirmed that among the three types of U. ohnoi oil, U. ohnoi oil of B contained the highest polyphenol as $107.45 \pm 0 \mathrm{mg} \mathrm{GAE} / \mathrm{g}$. This confirms that $U$. ohnoi oil exhibits a function that can replace krill oil, an animal oil. In addition, the efficacy of antioxidants was repeatedly confirmed through additional experiments. Since the existing oils with excellent antioxidant efficacy are being used in abundance in the food and cosmetics industry, it is possible to industrially use U. ohnoi oil, which has antioxidant properties.

Meanwhile, as a result of evaluating the antibacterial activity of $U$. ohnoi oil using URDA method, B. subtilis and E. coli strains showed strong antibacterial activity, but no antibacterial activity was observed for C. albicans. In the B. subtilis strain, the U. ohnoi oil from B showed higher activity than the U. ohnoi oils from other regions, and there was no significant difference in the C. albicans strain. The change in antibacterial activity was measured by treating six enzymes to investigate the properties of the antibacterial active ingredients of U. ohnoi oil, but there was no significant change compared with before treating enzymes. Ulva ohnoi oil showed some antibacterial activity, and this is a result that can prove the wide utility of U. ohnoi oil. In addition, it can be suggested as one of the many causes of reduced inflammation in the research results related to colitis.

After inducing inflammatory bowel disease with DSS, this study examined the anti-inflammatory effect by administering krill oil, $\omega-3$, and $U$. ohnoi oil. Compared with the normal group, weight loss and diarrhea were observed in all groups administered with DSS. In terms of proof, the U. ohnoi oil administered group and the normal group produced a similar amount of NO (an inflammation mediator) compared to the control group, indicating the effect of $U$. ohnoi oil to inhibit NO production. The inhibition of production of TNF- $\alpha$ IL- 6 , and IL- $1 \beta$ of $U$. ohnoi oil was measured through ELISA. The production of cytokines increased significantly the control group compared to the normal group, and the production was inhibited in the U. ohnoi group. The exact 


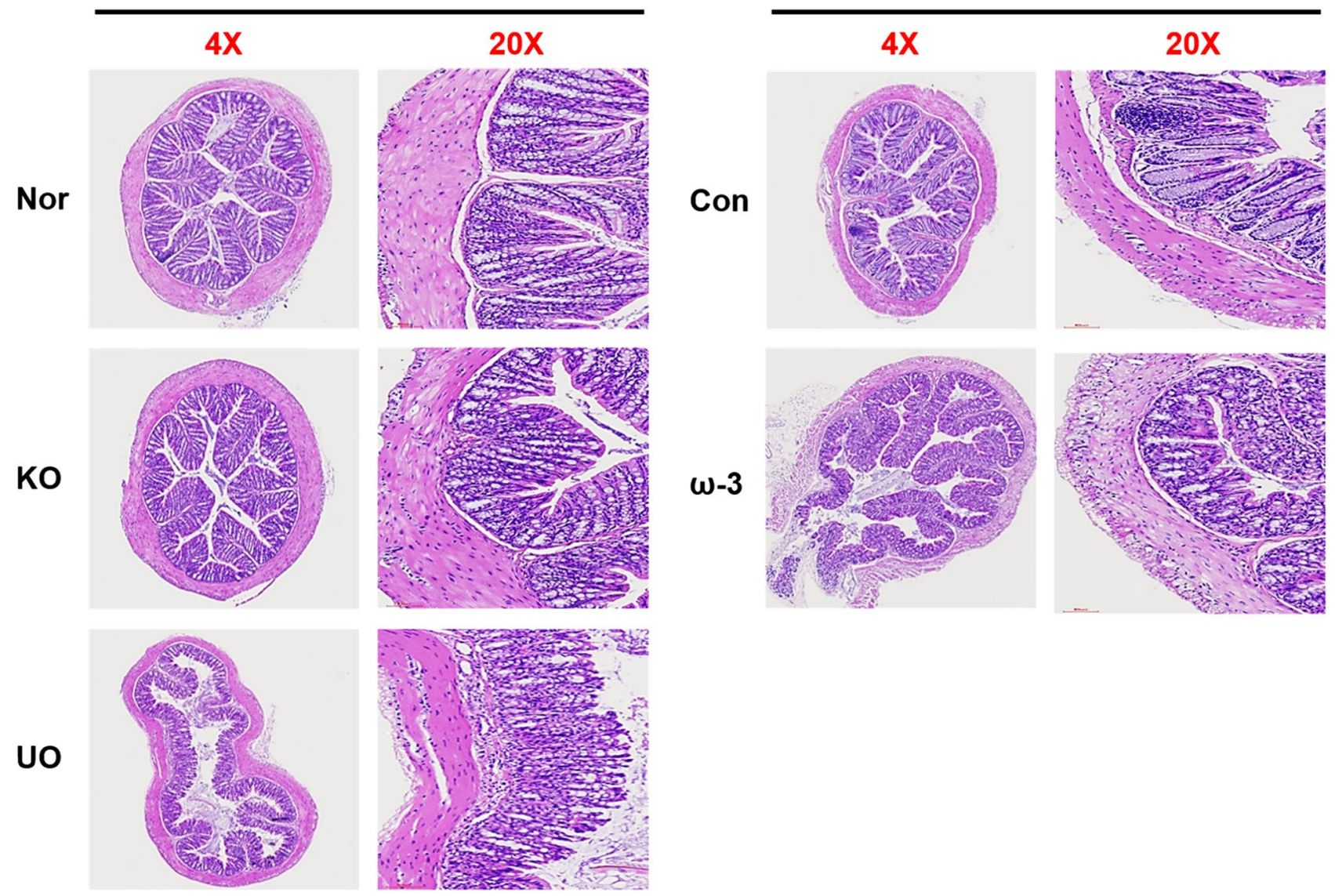

Figure 4. The colon tissue was section to a thickness of $7 \mu \mathrm{m}$ and stained with H\&E. Histologic observation of the intestine induced by DSS. Normal: without of DSS, Control: DSS-induced colitis, KO: DSS and krill oil $100 \mathrm{mg} / \mathrm{kg}$ administration, $\omega-3$ : DSS and $\omega-3100 \mathrm{mg} / \mathrm{kg}$ administration, and UO: DSS and U. ohnoi oil $25 \mathrm{mg} /$ kg administration. $\mathrm{n}=6$.

mechanism for the effectiveness of Ulva ohnoi oil to inhibit inflammatory cytokines will need to be investigated through future studies.

In case of TNF- $\alpha$ and IL-6, the U. ohnoi oil group showed a significant decrease compared to the control group. In case of the mRNA expression of inflammatory factors (TNF- $\alpha$, IL-6, IL-1 $\beta$, and COX-2) in the colon tissue, the $U$. ohnoi oil group showed similar expression levels to the krill oil administered group. These results support the results of measuring inflammatory cytokines in colon tissue.

As a result of analyzing the inflammatory response of the colon tissue using H\&E staining, the group that induced bowel disease with DSS showed crypt loss and inflammatory cell infiltration, but this was mitigated in the mice treated with DSS U. ohnoi. These results show that $U$. ohnoi oil has a higher anti-inflammatory effect than krill oil in mice with DSS-induced inflammatory bowel disease, and that it was effective in inhibiting inflammatory expression.

Krill oil, which has previously been helping health, needs an alternative material due to the decrease in krill shrimp. It is similar to the efficacy of krill oil, which is the U. ohnoi oil used in this study, and the one-minute efficacy is more beneficial. The $U$. ohnoi is being multiplied due to the warming of the climate, and the part that can be used in the industry is extremely weak. As the result of this study, it is expected that if the usefulness of $U$. ohnoi oil is utilized in industry, there will be a synergistic effect of reducing environmental pollution and utilizing biomass.

Statistical analysis. Data were analyzed using the predictive analytics software (PASW 18 for Windows) and presented as mean \pm S.D. A one-way analysis of variance (ANOVA) test was performed to assess the NO production in mouse plasma and the generation of inflammatory cytokines in the colon. The significance level was set at ${ }^{*} p<0.05$.

\section{Data availability}

The datasets used and/or analyzed during the current study are available from the corresponding author upon reasonable request. 
Received: 23 March 2021; Accepted: 9 July 2021

Published online: 23 July 2021

\section{References}

1. Oberley, T. D., Schultz, J. L., Li, N. \& Oberley, L. W. Antioxidant enzyme levels as a function of growth state in cell culture. Free Radical Biol. Med. 19, 53-65 (1995).

2. Shindo, Y. \& Hashimoto, T. Time course of changes in antioxidant enzymes in human skin fibroblasts after UV irradiation. J. Dermatol. Sci. 14, 225-232 (1997).

3. Aruoma, O. I. Nutrition and health aspects of free radicals and antioxidants. Food Chem. Toxicol. 32, 671-683 (1994).

4. Davies, K. J. \& Goldberg, A. L. Proteins damaged by oxygen radicals are rapidly degraded in extracts of red blood cells. J. Biol. Chem. 262, 8227-8234 (1987).

5. Machlin, L. J. \& Bendich, A. Free radical tissue damage: Protective role of antioxidant nutrients 1. Feder. Am. Soc. Exp. Biol. 1, 441-445 (1987).

6. Hatano, T. Constituents of natural medicines with scavenging effects on active oxygen species-tannins and related polyphenols. Nat. Med. 49, 357-363 (1995).

7. Kitahara, K., Matsumoto, Y., Ueda, H. \& Ueoka, R. A remarkable antioxidation effect of natural phenol derivatives on the autoxidation of $\gamma$-irradiated methyl linoleate. Chem. Pharm. Bull. 40, 2208-2209 (1992).

8. Hodge, H. C., Fassett, D. W., Maynard, E. A., Downs, W. L. \& Coye, R. D. Jr. Chronic feeding studies of butylated hydroxyanisole in dogs. Toxicol. Appl. Pharmacol. 6, 512-519 (1964).

9. Wilder, H. M., Ostby, P. C. \& Gregory, B. R. Effect of feeding butylated hydroxyanisole to dogs. J. Occup. Environ. Med. 3, 443 (1961).

10. Brown, W. D., Johnson, A. R. \& O'halloran, M. W. The effect of the level of dietary fat on the toxicity of phenolic antioxidants. Austr. J. Exp. Biol. Med. Sci. 37, 533-547 (1959).

11. Ophir, D., Hahn, T., Schattner, A., Wallach, D. \& Aviel, A. Tumor necrosis factor in middle ear effusions. Arch. Otolaryngol.-Head Neck Surg. 114, 1256-1258 (1988).

12. Berek, J. S. et al. Serum interleukin-6 levels correlate with disease status in patients with epithelial ovarian cancer. Am. J. Obstet. Gynecol. 164, 1038-1043 (1991).

13. Harris, J. et al. Autophagy controls IL-1 $\beta$ secretion by targeting pro-IL-1 $\beta$ for degradation. J. Biol. Chem. 286, 9587-9597 (2011).

14. Vane, J. R. et al. Inducible isoforms of cyclooxygenase and nitric-oxide synthase in inflammation. Proc. Natl. Acad. Sci. 91, 2046-2050 (1994)

15. Cosme, R., Lublin, D., Takafuji, V., Lynch, K. \& Roche, J. K. Prostanoids in human colonic mucosa: Effects of inflammation on PGE2 receptor expression. Hum. Immunol. 61, 684-696 (2000).

16. Nathan, C. Nitric oxide as a secretory product of mammalian cells. Feder. Am. Soc. Exp. Biol. 6, 3051-3064 (1992).

17. Nathan, C. \& Xie, Q. W. Nitric oxide synthases: Roles, tolls, and controls. Cell 78, 915-918 (1994).

18. Bhargava, R., Kumar, P., Kumar, M., Mehra, N. \& Mishra, A. A randomized controlled trial of omega-3 fatty acids in dry eye syndrome. Int. J. Ophthalmol. 6, 811 (2013).

19. Adarme-Vega, T. C., Thomas-Hall, S. R., Lim, D. K. \& Schenk, P. M. Effects of long chain fatty acid synthesis and associated gene expression in microalga Tetraselmis sp. Mar. Drugs 12, 3381-3398 (2014).

20. Ulven, S. M. et al. Metabolic effects of krill oil are essentially similar to those of fish oil but at lower dose of EPA and DHA, in healthy volunteers. Lipids 46, 37-46 (2011).

21. Ulven, S. M. \& Holven, K. B. Comparison of bioavailability of krill oil versus fish oil and health effect. Vasc. Health Risk Manag. 11, $511(2015)$

22. Ishiguro, K. et al. Distribution of fluoride in cortical bone of human rib. Calcif. Tissue Int. 52, 278-282 (1993).

23. Hill, S. L., Atkinson, A., Pakhomov, E. A. \& Siegel, V. Evidence for a decline in the population density of Antarctic krill Euphausia superba still stands. A comment on Cox et al. J. Crustacean Biol. 39, 316-322 (2019).

24. Steinmetz, K. A. \& Potter, J. D. Vegetables, fruit, and cancer II. Mechanisms. Cancer Causes Control. 2, 427-442 (1991).

25. Le Tutour, B. et al. Antioxidant and pro-oxidant activities of the brown algae, Laminaria digitata, Himanthalia elongata, Fucus vesiculosus, Fucus serratus and Ascophyllum nodosum. J. Appl. Phycol. 10, 121 (1998).

26. Kim, J. H., Kim, S. A., Edwards, M. S. \& Lee, I. A. Anti-inflammatory effects of polyphenol extracts from Ulva linza (Ulvophyceae, Chlorophyta). Toxicol. Environ. Health Sci. 10, 212-219 (2018).

27. Fujimura, T. \& Tsukahara, K. vesiculosus chanoes its thickness and mechanical properties. J. Cosmet. Sci. 53, 1-9 (2002).

28. Mabeau, S. \& Fleurence, J. Seaweed in food products: Biochemical and nutritional aspects. Trends Food Sci. Technol. 4, 103-107 (1993).

29. Funahashi, H. et al. Seaweed prevents breast cancer. Jpn. J. Cancer Oncol. Res. 92, 483-487 (2001).

30. Kang, E. J., Han, A. R., Kim J. H., Kim, I. N., Lee S., Min, J. O., Nam, B. R., Choi, Y. J., Edwards, M. S., Diaz-Pulido, G. \& Kim, C. Evaluating bloom potential of the green-tide forming alga Ulva ohnoi under ocean acidification and warming. Sci. Total Environ. $769(2021)$.

31. Ohno, M. Ulva as New Food Stuff in Utilization of Ulva spp. and Environmental Restoration (ed. Notoya, M.) 137-143 (Seizando, 1999).

32. Ryu, B. H., Kim, D. S., Cho, K. J. \& Sin, D. B. Antitumor activity of seaweeds toward sarcoma-180. Korean J. Food Sci. Technol. 21, 595-600 (1989).

33. Senba, Y., Nishishita, T., Saito, K., Yoshioka, H. \& Yoshioka, H. Stopped-flow and spectrophotometric study on radical scavenging by tea catechins and the model compounds. Chem. Pharm. Bull. 47, 1369-1374 (1999).

34. Singleton, V. L. \& Rossi, J. A. Colorimetry of total phenolics with phosphomolybdic-phosphotungstic acid reagents. Am. J. Enol. Vitic. 16, 144-158 (1965).

35. Lehrer, R. I., Rosenman, M., Harwig, S. S., Jackson, R. \& Eisenhauer, P. Ultrasensitive assays for endogenous antimicrobial polypeptides. J. Immunol. Methods 137, 167-173 (1991).

36. Delgado Alves, J., Mason, L. J., Ames, P. R. J., Chen, P. P., Rauch, J., Levine, J. S., Subang, R. \& Isenberg, D. A. Antiphospholipid antibodies are associated with enhanced oxidative stress, decreased plasma nitric oxide and paraoxonase activity in an experimental mouse model. Rheumatology 44, 1238-1244 (2005).

37. Bayramoglu, N., Kaakinen, M., Eklund, L., \& Heikkila, J. Towards virtual h\&e staining of hyperspectral lung histology images using conditional generative adversarial networks. pp. 64-71. in 2017 IEEE International Conference on Computer Vision Workshop. October 22, Venice, Italy. (IEEE Computer Society, 2017).

38. Fischer, A. H., Jacobson, K. A., Rose, J. \& Zeller, R. Hematoxylin and eosin staining of tissue and cell sections. Cold Spring Harbor Protoc. 2008 pdb-prot4986 (2008).

39. Strieter, R. M., Kunkel, S. L. \& Bone, R. C. Role of tumor necrosis factor-alpha in disease states and inflammation. Crit. Care Med. 21, S447-S463 (1993). 


\section{Acknowledgements}

This research was supported by funds of National Research Foundation (NRF-2019R1A4A1026423).

\section{Author contributions}

I.A.L. and J.E.K. conceived and designed the experiments and wrote the paper. J.S.P., J.K.S., W.H.C., and J.H.K. performed experiments and analyzed data. S.C.C. performed the necessary supplementary experiments for the manuscript. All authors read and approved the final manuscript.

\section{Competing interests}

The authors declare no competing interests.

\section{Additional information}

Supplementary Information The online version contains supplementary material available at https://doi.org/ 10.1038/s41598-021-94475-Z.

Correspondence and requests for materials should be addressed to I.-A.L.

Reprints and permissions information is available at www.nature.com/reprints.

Publisher's note Springer Nature remains neutral with regard to jurisdictional claims in published maps and institutional affiliations.

(c) (i) Open Access This article is licensed under a Creative Commons Attribution 4.0 International License, which permits use, sharing, adaptation, distribution and reproduction in any medium or format, as long as you give appropriate credit to the original author(s) and the source, provide a link to the Creative Commons licence, and indicate if changes were made. The images or other third party material in this article are included in the article's Creative Commons licence, unless indicated otherwise in a credit line to the material. If material is not included in the article's Creative Commons licence and your intended use is not permitted by statutory regulation or exceeds the permitted use, you will need to obtain permission directly from the copyright holder. To view a copy of this licence, visit http://creativecommons.org/licenses/by/4.0/.

(C) The Author(s) 2021 